\title{
Influence of Roasting Temperatures on the Antioxidant Properties, $\beta$-Glucan Content, and Volatile Flavor Profiles of Shiitake Mushroom
}

\author{
In-Seo Hwang ${ }^{1,+}$, Seo-Yeong Chon ${ }^{1,+}$, Woo-Suk Bang ${ }^{2, *, \ddagger}$ and Mina K. Kim ${ }^{1, *, \ddagger(D)}$ \\ 1 Department of Food Science and Human Nutrition and Fermented Food Research Center, \\ Jeonbuk National University, 567 Baekjedaero, Deokjin-gu, Jeonju-si 54896, Jeonbuk, Korea; \\ his0753@naver.com (I.-S.H.); tjdud1128@naver.com (S.-Y.C.) \\ 2 Department of Food and Nutrition, Yeungnam University, 280, Daehak-ro, Gyeongsan 712-749, Korea \\ * Correspondence: wsbang@ynu.ac.kr (W.-S.B.); minakim@jbnu.ac.kr (M.K.K.); Tel.: +82-63-270-3879 \\ + In-Seo Hwang and Seo-Yeong Chon contributed to this work equally as co-first authors. \\ $\ddagger$ Woo-Suk Bang and Mina K. Kim contributed equally to this work as co-coresponding authors.
}

Citation: Hwang, I.-S.; Chon, S.-Y.; Bang, W.-S.; Kim, M.K. Influence of Roasting Temperatures on the Antioxidant Properties, $\beta$-Glucan Content, and Volatile Flavor Profiles of Shiitake Mushroom. Foods 2021, 10 54. https://dx.doi.org/ $10.3390 /$ foods 10010054

Received: 2 December 2020 Accepted: 24 December 2020 Published: 28 December 2020

Publisher's Note: MDPI stays neutral with regard to jurisdictional claims in published maps and institutional affiliations.

Copyright: (C) 2020 by the authors. Licensee MDPI, Basel, Switzerland. This article is an open access article distributed under the terms and conditions of the Creative Commons Attribution (CC BY) license (https: / / creativecommons.org/ licenses/by/4.0/).

\begin{abstract}
The objective of this study was to determine the influence of roasting conditions on the volatile flavor profiles and functional properties of shiitake mushrooms. Six different roasting temperatures between $80{ }^{\circ} \mathrm{C}$ and $180{ }^{\circ} \mathrm{C}$ with $20{ }^{\circ} \mathrm{C}$ increments were selected, and mushrooms were roasted for $60 \mathrm{~min}$ in a conventional oven. Roasting shiitake mushroom at $140{ }^{\circ} \mathrm{C}$ showed the highest levels of antioxidant activities including 2,2'-azino-bis (3-ethylbenzothiazoline-6-sulfonic acid) (ABTS) and 2,2-diphenyl-1-picrylhidrazyl (DPPH) radical scavenging activities, total phenols and polyphenol contents. The $\beta$-glucan ranged from $34.85 \%$ to $41.49 \%$, and it was highest when the mushrooms were roasted at $120^{\circ} \mathrm{C}$, followed by $140{ }^{\circ} \mathrm{C}$. Instrumental flavor analysis was conducted by Gas Chromatography using Purge and Trap, and identification of compounds were produced by NIST library. Twenty-six volatile flavor compounds were identified. The concentrations of pyrazines and furans increased with increased roasting temperatures. Shiitake mushrooms roasted at $160{ }^{\circ} \mathrm{C}$ for $60 \mathrm{~min}$ had the most diverse volatile flavor compound profiles. This study revealed how roasting temperatures can modulate antioxidant, functional ( $\beta$-glucan) and flavor benefits.
\end{abstract}

Keywords: shiitake mushroom; beta-glucan; antioxidant properties

\section{Introduction}

The shiitake mushroom (Lentinus edodes), one of the most cultivated mushroom in the world, has been widely incorporated into various cuisines, especially in East Asia [1]. Due to the presence of various bioactive compounds, including vitamins B1, B2, and C, dietary fiber, folate, niacin, polysaccharides, some minerals and ergosterols, consumers eat shiitake mushrooms for their unique taste and nutritional benefits [2]. In Korea, the consumption of shiitake mushrooms has been increasing since 2000; around 30,000 metric tons were consumed as of 2005 [3]. Commercialized cultivation is also available, by inoculation of mushroom spore in the dried wood, and cultivation is at its optimal at the temperature around $10-20{ }^{\circ} \mathrm{C}$ with $60-70 \%$ humidity. Shiitake mushrooms can be harvested from March to September in Korea. Mushrooms harvested in March are regarded as the best quality, as these give the most intense aroma with a unique texture. Consequently, many producers harvest mushrooms in March and distribute the mushrooms year round after processing (drying, freeze-drying, and/or spray drying). During the drying process, the taste and aroma components are concentrated due to the moisture loss, thus enhancing the unique taste of shiitake mushrooms [1].

Many studies related to shiitake mushrooms have been conducted, especially regarding the functional properties, the identification and extractions of the taste components, and 
flavor analysis. For example, $\beta$-glucan found in high levels in shiitake mushrooms has beneficial health functional properties: for example, anti-tumor and anti-cancer activities [4-6]. High antioxidant properties and an effect to decrease levels of blood cholesterol have also been reported $[2,7,8]$. Studies reporting shiitake mushrooms' flavor characteristics can be classified into two groups: non-volatile compounds responsible for umami tastes and volatile compounds responsible for mushroom aromatics $[9,10]$. Non-volatile components including free amino acids, nucleotides and soluble carbohydrates are well-known compounds responsible for umami tastes; the aqueous extracts of shiitake mushrooms have therefore been widely utilized in the preparation of vegetable broths (dashi) and flavor enhancers [1,10]. 1-octen-3-ol has been well reported as the key aroma compound responsible for raw mushroom aromatics [9,11]. In addition to 1-octen-3-ol, many sulfurcontaining compounds, including dimethyl disulfide (DMDS), dimethyl trisulfide (DMTS), and cyclic sulfur compounds, have been identified as key contributors to the distinctive shiitake mushroom flavor [12]. However, the above-mentioned studies focused only on the volatile flavor analysis or the functional benefits of shiitake mushrooms. A comprehensive understanding of shiitake mushrooms in relation to flavor and functionality is still missing. The objective of this study was to determine the influence of roasting conditions on the volatile flavor profiles and functional properties of shiitake mushrooms.

\section{Materials and Methods}

\subsection{Sample Preparation}

The shiitake mushrooms included in this study were purchased through direct contact with a local producer (Suhwooms, Iksan, Korea) and stored at $4{ }^{\circ} \mathrm{C}$ before roasting. The mushrooms were sliced at a thickness of four millimeters before roasting. The thickness and roasting conditions of the shiitake mushrooms were selected based on a PI's preliminary study. Six roasting temperatures were selected: $80^{\circ} \mathrm{C}, 100{ }^{\circ} \mathrm{C}, 120^{\circ} \mathrm{C}, 140{ }^{\circ} \mathrm{C}, 160{ }^{\circ} \mathrm{C}$, and $180^{\circ} \mathrm{C}$. All the samples were roasted for $60 \mathrm{~min}$ since sample roasted for $60 \mathrm{~min}$ showed the highest sensory acceptance in previous study. using a commercial convection oven (COR-030K, Dongyang-magic, Seoul, Korea). After roasting, samples were stored at room temperature in dried atmosphere with moisture absorber.

\subsection{Antioxidant Properties}

The polyphenolic compounds (free- and bound-) of shiitake mushrooms were extracted using the Folin-Ciocalteu method of Krygier, Sosulski, and Hogge (1982). Result from this method was expressed as mg (+)-catechin equivalents per $100 \mathrm{~g}$ of shiitake mushrooms [13]. First, $3 \mathrm{~g}$ of roasted shiitake mushrooms were finely ground using an electronic blender (NINJA BL682KR, Hai Xin Technology Company, Shenzhen, China), and $20 \mathrm{~mL}$ of $80 \%$ ethanol was added and thoroughly mixed using a vortex mixer (VM-10, Daihan Scientific Co., Wonju, Korea) at room temperature $\left(25^{\circ} \mathrm{C}\right)$ for $10 \mathrm{~min}$. Then, this mixture was centrifuged at 10,000 rpm for $10 \mathrm{~min}$. Upon completion, the supernatant was collected and further concentrated at $40^{\circ} \mathrm{C}$ to $2 \mathrm{~mL}$ using a rotary vacuum evaporator. Then, $20 \mathrm{~mL}$ of distilled water was added and the supernatant was stored at $-20{ }^{\circ} \mathrm{C}$ til further analysis. The residues separated from the supernatant solution were hydrolyzed using $4 \mathrm{~mL}$ of $4 \mathrm{~N} \mathrm{NaOH}$ for sixty minutes and adjusted to $\mathrm{pH} 2$ with $6 \mathrm{~N} \mathrm{HCl}$. Then, $4 \mathrm{~mL}$ of ethyl acetate was added and thoroughly mixed into the solution, and the residues were collected; this procedure was repeated six times. The collected extracts were further concentrated to $2 \mathrm{~mL}$ by a rotary vacuum evaporator at $40^{\circ} \mathrm{C}$; distilled water was added up to $10 \mathrm{~mL}$, and this extracts were stored at $-20^{\circ} \mathrm{C}$ until further analysis.

Gallic acid (Sigma-Aldrich, St. Louis, MO, USA) was used for the standard curve, and total polyphenol content was reported in the mg GAE/100 g sample. A mixture of $0.2 \mathrm{~mL}$ of the extract with $0.2 \mathrm{~mL}$ Folin-Cioculteu reagent was left at room temperature for three minutes. Then, $0.4 \mathrm{~mL}$ of $10 \% \mathrm{Na}_{2} \mathrm{CO}_{3}$ and $4 \mathrm{~mL}$ of distilled water was added and left in the dark room for sixty minutes. A $1 \mathrm{~mL}$ of final mixture was inserted in a cuvette (Ratiolab cuvets, semi-micro, Hungary) and the absorbance was measured at $720 \mathrm{~nm}$ using 
a spectrophotometer (BioDrop, MET Laboratories, Inc., Baltimore, MD, USA). All analysis was conducted in triplicate.

The DPPH radicals of the extracts were measured using a previously reported method with minor modifications [14]: $4 \mathrm{~mL}$ of $0.2 \mathrm{mM} \mathrm{DPPH}$ solution and $4 \mathrm{~mL}$ of extract were thoroughly mixed and left in a dark room for $10 \mathrm{~min}$ at room temperature. The absorbance was measured at $520 \mathrm{~nm}$ using a spectrophotometer (BioDrop, MET Laboratories, Inc., Baltimore, MD, USA). The DPPH radical scavenging activity (\%) was calculated by the Equation (1) as below:

$$
\text { Radical scavenging activity }(\%)=\left(\left(1-\mathrm{A}_{\text {sample }}\right) /\left(\mathrm{A}_{\text {control }}\right)\right) \times 100
$$

where $A_{\text {sample }}$ represents the sample absorbance and $A_{\text {control }}$ represents the control absorbance.

The scavenging activity of the shiitake extract was measured using the $\mathrm{ABTS}^{+}$decolorization assay method. After mixing $7 \mathrm{mM}$ (Sigma Chemical Co., St. Louis, MI, USA) and $2.45 \mathrm{mM}$ of potassium persulfate, the solution was left in the dark room for one day at the room temperature $\left(25^{\circ} \mathrm{C}\right)$ to form $\mathrm{ABTS}^{+}$. The solution was then diluted with distilled water to obtain an absorbance of 1.4-1.5 at $734 \mathrm{~nm}$. The absorbance of a mixture of $50 \mu \mathrm{L}$ of the extract solution and $1 \mathrm{~mL}$ of a diluted $\mathrm{ABTS}^{+}$solution was measured at $734 \mathrm{~nm}$ using a spectrophotometer (BioDrop, MET Laboratories, Inc., Baltimore, MD, USA). Trolox (Sigma Chemical Co., St. Louis, MI, USA) was used to obtain the standard curve. The Trolox equivalent antioxidant capacity (TEAC) was calculated using Equation (2) as below:

$$
\operatorname{TEAC}(\mathrm{mg} \text { Trolox eq })=\left(\Delta \mathrm{A}_{\text {sample }}\right) /\left(\Delta \mathrm{A}_{\text {Trolox }}\right) \times(T C / S C)
$$

where $\Delta \mathrm{A}$ (sample) represents the change of absorbance when extracts are added, and $\Delta \mathrm{A}$ (Trolox) represents the change in absorbance when Trolox standard solution is added, $T C$ represents the concentration $(\mathrm{mg} / \mathrm{mL}$ ) of the Trolox standard solution, and $S C$ represents the concentration of the sample $(\mathrm{mg} / \mathrm{mL})$. All the extracts were analyzed in triplicate.

\section{3. $\beta$-Glucan and Other Glucan Content}

A $\beta$-glucan assay kit for mushroom and yeast (K-YBGL, Megazyme, Wicklow, Ireland) was used for glucan content analysis in the roasted shiitake mushroom samples. Analysis of the total glucan, $\alpha$-, and $\beta$-glucan was conducted simultaneously. For the total glucan analysis, $1.5 \mathrm{~mL}$ of $37 \% \mathrm{HCl}$ (Sigma-Aldrich Chemical Company, St. Louis, USA) was added to $100 \mathrm{mg}$ of a shiitake mushroom and then, placed in an ice water bath $\left(0{ }^{\circ} \mathrm{C}\right)$ for $20 \mathrm{~min}$. Then, $10 \mathrm{~mL}$ of distilled water was added and incubated at $100^{\circ} \mathrm{C}$ for two hours. After the samples cooled down to room temperature, $10 \mathrm{~mL}$ of $2 \mathrm{~N} \mathrm{KOH}$ (Sigma-Aldrich Chemical Company, St. Louis, MO, USA) was added to each sample and mixed thoroughly using a vortex mixer (VM-10, Daihan Scientific, Seoul, Korea) at a speed of $4000 \mathrm{rpm}$. Each sample was transferred to a volumetric flask and adjusted to $100 \mathrm{~mL}$ with a $0.2 \mathrm{M}$ sodium acetate buffer at $\mathrm{pH} 5.0$. The samples were then centrifuged at 10,000 rpm for $10 \mathrm{~min}$. Then, $0.1 \mathrm{~mL}$ of supernatant was collected and $0.1 \mathrm{~mL}$ of exo- $1,3-\beta$-glucanase $(20 \mathrm{U} / \mathrm{mL})$ and $\beta$-glucosidase $(4 \mathrm{U} / \mathrm{mL})$ solution was added to this supernatant and incubated at $40{ }^{\circ} \mathrm{C}$ for $60 \mathrm{~min}$. Finally, $3 \mathrm{~mL}$ of glucose oxidase/peroxidase (GOPOD) solution was added to the final sample and were sit for $20 \mathrm{~min}$ at $40{ }^{\circ} \mathrm{C}$ to react. The total glucan was measured in the absorbance set at $510 \mathrm{~nm}$ using spectrophotometry (Biodrop Duo, Biodrop, Cambridge, United Kingdom) for each roasted shiitake mushroom sample.

Once the total glucan contents were analyzed, the $\alpha$-glucan contents were analyzed as follows: $2 \mathrm{~mL}$ of $2 \mathrm{~N} \mathrm{KOH}$ (Sigma-Aldrich Chemical Company, St. Louis, MI, USA) was added to $100 \mathrm{mg}$ of a shiitake mushroom sample and placed in a $30{ }^{\circ} \mathrm{C}$ water bath for $45 \mathrm{~min}$. Then, $8 \mathrm{~mL}$ of $1.2 \mathrm{M}$ sodium acetate buffer ( $\mathrm{pH} 3.8$ ), $0.2 \mathrm{~mL}$ of amyloglucosidase $(1630 \mathrm{U} / \mathrm{mL})$, and an invertase $(500 \mathrm{U} / \mathrm{mL})$ solution were added. Then, the mixture was placed in water bath with a temperature set at $40{ }^{\circ} \mathrm{C}$ for $30 \mathrm{~min}$. The samples were centrifuged at $4000 \mathrm{rpm}$ for $10 \mathrm{~min}$, and $0.1 \mathrm{~mL}$ of supernatant was transferred to a solution 
containing $0.1 \mathrm{~mL}$ of $0.2 \mathrm{M}$ sodium acetate buffer (pH 5.0) and $3 \mathrm{~mL}$ of GOPOD. The final samples were reacted at $40{ }^{\circ} \mathrm{C}$ for $20 \mathrm{~min}$. The $\alpha$-glucan absorbance was measured at $510 \mathrm{~nm}$ using spectrophotometry. The glucose standard $(1 \mathrm{mg} / \mathrm{mL})$ solution was used as a control standard, and a $0.2 \mathrm{M}$ sodium acetate buffer set at $\mathrm{pH} 5.0$ was used for a blank. The determination of the $\beta$-glucan content was calculated by subtracting the $\alpha$-glucan content from the total glucan content. Each content $(\%, w / w)$ was calculated using absorbance values with Mega-Calc ${ }^{\mathrm{TM}}$.

\subsection{Volatile Flavor Analysis}

The volatile flavor analysis was conducted by purge and trap (P\&T) sampler (JTD505III, Japan Analytical Industry, Tokyo, Japan) followed by gas chromatograph-mass spectrometry (GC-MS; QP2010 Plus, Shimadzu, Kyoto, Japan). Prior to the P\&T sampling, roasted shiitake mushroom samples went through a bubbling process at a rate of $50 \mathrm{~mL} / \mathrm{min}$ for $30 \mathrm{~min}$ at a temperature set at $60^{\circ} \mathrm{C}$ in AQ-200 liquid sampler (Japan Analytical Industry, Tokyo, Japan) to capture the volatile aromatic compounds. Upon completion of bubbling process, volatile aromatic compounds were absorbed in Tenax GR (Japan Analytical Industry, Tokyo, Japan). This Tenax GR was transferred to the P\&T sampler. The desorption temperature in the P\&T sampler was set at $280^{\circ} \mathrm{C}$ for $30 \mathrm{~min}$ at a rate of $50 \mathrm{~mL} / \mathrm{min}$, followed by the cold trap set at $-40{ }^{\circ} \mathrm{C}$, and pyrolysis was applied at the temperature set at $280^{\circ} \mathrm{C}$. The temperature for both transfer line and needle heater was also set at $280^{\circ} \mathrm{C}$. The head press for the P\&T sampler was adjusted at $86 \mathrm{MPa}$, and flow rate in the column was set at $1.0 \mathrm{~mL} / \mathrm{min}$ with a $1 / 100$ split ratio.

For the quantification and qualification of volatile compounds, GC-MS QP2010 Plus equipped with DB-624 column $(30 \mathrm{~m} \times 0.251 \mathrm{~mm} \times 1.40 \mathrm{~mm}$; Agilent Technologies, Wilmington, DE, USA) was used. The temperature in the GC-MS oven was programmed as followings: $40{ }^{\circ} \mathrm{C}$ for 3-min hold, then the temperature was increased at a speed of $10{ }^{\circ} \mathrm{C} /$ minute up to $260{ }^{\circ} \mathrm{C}$, then held for $5 \mathrm{~min}$ at $260{ }^{\circ} \mathrm{C}$. The mass spectrometer was operated with full scan mode with positive electron impact ionization mode with $70 \mathrm{eV}$ of electron energy. The scan range was set between 45 and $500 \mathrm{~m} / \mathrm{z}$. The peak area ratio (PAR) for each volatile compound was calculated as peak area height divided by total peak area. The volatile compounds were identified by mass spectrum in the Wiley mass spectral databases (NIST08, Wiley). All volatile flavor analysis was carried out at CURF in Jeonbuk National University.

\subsection{Statistical Analysis}

The antioxidant properties and glucan contents were expressed as the mean \pm standard deviation of a triplicate analyses, and a significant difference among shiitake mushrooms roasted different temperatures was determined by analysis of variance (ANOVA) followed by Duncan's multiple range test at the level of $\alpha=0.05$ for roasting-related attributes, antioxidant properties, peak area ratio, and $\alpha=0.10$ for glutan $(\alpha-, \beta-$, and total) contents. Prior to run ANOVA, data normality and equal variance assumptions have been checked. A principal component analysis (PCA) was conducted to define the location of each shiitake mushroom sample in the antioxidant, glucan, and volatile flavor analysis map using 2018 XLSTAT software (Addinsoft, Paris, France). All other analyses were performed using SPSS (version 25.0; IBM, Amonk. New York, NY, USA).

\section{Results}

\subsection{Antioxidant Properties}

The length and weight of shiitake mushrooms before and after roasting according to the roasting temperature $\left(80,100,120,140,160,180^{\circ} \mathrm{C}\right)$, and the corresponding reduction rate of length and weight, are shown in Table 1 . It can be seen that the length reduction rate from $120^{\circ} \mathrm{C}$ to $180^{\circ} \mathrm{C}$ was $25 \%$ to $31 \%$, significantly higher than the reduction rate at $80^{\circ} \mathrm{C}$ and $100{ }^{\circ} \mathrm{C}(10.42,14.01 \%$ respectively) $(p<0.05)$. Weight reduction rates also tended to be similar to length reduction rates. The lowest reduction rate $(68.06 \%)$ at $80{ }^{\circ} \mathrm{C}$ was 
shown, and the length reduction rate was increased as the roasting temperature increased. It can be seen that the weight reduction rate at $140-180{ }^{\circ} \mathrm{C}$ was significantly higher than the reduction rate at the low roasting temperature $(p<0.05)$. Therefore, we could see that the rate of reduction in length and weight increased as the roasting temperature increased.

The antioxidant contents of shiitake mushrooms roasted at different temperatures are shown in Table 2. Significant differences between the shiitake samples were observed in the DPPH radical scavenging activity. The highest antioxidant contents were observed at $80{ }^{\circ} \mathrm{C}, 140{ }^{\circ} \mathrm{C}$, and $160{ }^{\circ} \mathrm{C}$ with $83.74 \%, 82.32 \%$, and $82.64 \%$, respectively $(p<0.05)$. The highest free total phenol levels were observed in shiitake mushrooms roasted at $140{ }^{\circ} \mathrm{C}$ and $160{ }^{\circ} \mathrm{C}: 0.52 \mathrm{mg}$ and $0.51 \mathrm{mg}$, respectively. The bound total phenol level was observed best at $140^{\circ} \mathrm{C}$. Therefore, the maximum total phenol content was seen at $140{ }^{\circ} \mathrm{C}$. Like the total phenol content, the polyphenol content was expressed as mg of gallic acid compounds per $100 \mathrm{~g}$ of sample (weighed as is). The highest content of polyphenols was $0.81 \mathrm{mg}$ at $140{ }^{\circ} \mathrm{C}$ and $160^{\circ} \mathrm{C}$, and the lowest content was observed as $0.62 \mathrm{mg}$ at $80^{\circ} \mathrm{C}$ and $180{ }^{\circ} \mathrm{C}$. After heat treatment at $140{ }^{\circ} \mathrm{C}$ for $60 \mathrm{~min}$, the TEAC values were 4.23 and $4.89 \mathrm{mg}$ Trolox equivalents/100 g sample, respectively. Compared to previously reported antioxidant contents in shiitake mushrooms, the antioxidant contents reported in this study were in agreement with the antioxidant contents in other mushroom products. The highest antioxidant contents in shiitake mushrooms have been reported as $88.6 \%$ in shiitake mushrooms heated at $121^{\circ} \mathrm{C}$ for $30 \mathrm{~min}$. In addition, the free polyphenols were prone to increase as the temperature and the heating time increased [15]. An increase tendency of antioxidant properties with increased temperature was also reported [6]. Increase of antioxidant activities of shiitake mushroom with increase heat treatment temperatures may have been attributed from the deactivation of endogenous enzymes responsible for oxidation [15], and similar trend was also observed in many plant-origin products such as sweet corn [16], Citrus peel [17] and tomato [18].

Table 1. Samples included in this study.

\begin{tabular}{|c|c|c|c|c|c|c|}
\hline \multirow{2}{*}{ Roasting Conditions } & \multicolumn{2}{|c|}{ Before Roasting } & \multicolumn{3}{|c|}{ After Roasting } & \multirow[b]{2}{*}{ Weight Reduction (\%) } \\
\hline & Length (cm) & Weight (g) & Length (cm) & Weight (g) & Length Reduction (\%) & \\
\hline $80{ }^{\circ} \mathrm{C} 60 \mathrm{~min}$ & $7.03 \pm 0.05$ & $2.63 \pm 0.61$ & $6.3 \pm 0.24$ & $0.84 \pm 0.11$ & $10.42 \pm 3.55 b$ & $68.06 \pm 7.95 b$ \\
\hline $100^{\circ} \mathrm{C} 60 \mathrm{~min}$ & $7.6 \pm 0.08$ & $3.27 \pm 0.46$ & $6.53 \pm 0.21$ & $0.79 \pm 0.11$ & $14.01 \pm 3.16 b$ & $75.84 \pm 6.80 \mathrm{ab}$ \\
\hline $120^{\circ} \mathrm{C} 60 \mathrm{~min}$ & $5.87 \pm 0.21$ & $2.76 \pm 0.45$ & $4.03 \pm 0.05$ & $0.65 \pm 0.10$ & $31.14 \pm 3.21 \mathrm{a}$ & $76.36 \pm 2.37 \mathrm{ab}$ \\
\hline $140^{\circ} \mathrm{C} 60 \mathrm{~min}$ & $6.83 \pm 2.26$ & $2.78 \pm 0.33$ & $4.73 \pm 0.21$ & $0.47 \pm 0.03$ & $30.75 \pm 2.31 \mathrm{a}$ & $83.23 \pm 1.26 \mathrm{a}$ \\
\hline $160^{\circ} \mathrm{C} 60 \mathrm{~min}$ & $6.8 \pm 0.41$ & $2.95 \pm 0.47$ & $5.07 \pm 0.41$ & $0.54 \pm 0.14$ & $25.75 \pm 5.47 \mathrm{a}$ & $81.83 \pm 7.45 \mathrm{a}$ \\
\hline $180^{\circ} \mathrm{C} 60 \mathrm{~min}$ & $7.1 \pm 0.14$ & $3.06 \pm 0.63$ & $5.27 \pm 0.33$ & $0.56 \pm 0.09$ & $25.87 \pm 3.60 \mathrm{a}$ & $81.68 \pm 0.88 a$ \\
\hline
\end{tabular}

Means in a column that does not share the same alphabetical letter represent significant difference at $p<0.05$.

Table 2. Antioxidant properties of Shiitake mushroom roasted in different conditions.

\begin{tabular}{|c|c|c|c|c|c|c|}
\hline & \multirow{2}{*}{ DPPH (\%) } & \multicolumn{2}{|c|}{ Total Phenol } & \multirow{2}{*}{ Polyphenol } & \multicolumn{2}{|c|}{ TEAC (mmol/L) } \\
\hline & & Free & Bound & & Free & Bound \\
\hline $80^{\circ} \mathrm{C}$ & $83.74 \pm 0.77 a$ & $0.38 \pm 0.02 c$ & $1.28 \pm 0.02 c$ & $0.62 \pm 0.03 c$ & $2.13 \pm 0.02 \mathrm{f}$ & $4.03 \pm 0.01 \mathrm{~d}$ \\
\hline $100^{\circ} \mathrm{C}$ & $76.29 \pm 1.24 c$ & $0.42 \pm 0.02 b$ & $1.09 \pm 0.02 \mathrm{~d}$ & $0.70 \pm 0.04 b$ & $2.80 \pm 0.01 \mathrm{e}$ & $4.60 \pm 0.04 c$ \\
\hline $120^{\circ} \mathrm{C}$ & $78.87 \pm 1.43 b$ & $0.43 \pm 0.00 \mathrm{~b}$ & $0.98 \pm 0.02 \mathrm{e}$ & $0.70 \pm 0.01 \mathrm{~b}$ & $3.62 \pm 0.01 c$ & $4.78 \pm 0.01 \mathrm{~b}$ \\
\hline $140^{\circ} \mathrm{C}$ & $82.32 \pm 0.37 a$ & $0.52 \pm 0.02 \mathrm{a}$ & $1.31 \pm 0.03 c$ & $0.81 \pm 0.02 \mathrm{a}$ & $4.23 \pm 0.00 \mathrm{a}$ & $4.89 \pm 0.01 \mathrm{a}$ \\
\hline $160^{\circ} \mathrm{C}$ & $82.64 \pm 0.52 \mathrm{a}$ & $0.51 \pm 0.02 \mathrm{a}$ & $1.54 \pm 0.02 \mathrm{a}$ & $0.81 \pm 0.02 \mathrm{a}$ & $3.86 \pm 0.01 b$ & $3.15 \pm 0.02 \mathrm{f}$ \\
\hline $180^{\circ} \mathrm{C}$ & $50.66 \pm 1.51 \mathrm{~d}$ & $0.39 \pm 0.02 c$ & $1.42 \pm 0.03 b$ & $0.62 \pm 0.02 c$ & $2.93 \pm 0.00 \mathrm{~d}$ & $3.43 \pm 0.01 \mathrm{e}$ \\
\hline
\end{tabular}

Means in a column that does not share the same alphabetical letter represent significant difference at $p<0.05$.

\section{2. $\beta$-Glucan, Total, and $\alpha$-Glucan Analysis Results}

The $\beta$-glucan and other glucan (total and $\alpha$-) contents of shiitake mushrooms roasted at different temperatures are shown in Table 3. Significant differences in glucan were observed in the total $\alpha$ - and $\beta$-glucans among the shiitake mushroom samples $(p<0.10)$. 
The content of total glucan was at its highest when shiitake mushrooms were roasted at $120{ }^{\circ} \mathrm{C}$ for $60 \mathrm{~min}$, in that $41.61 \%$ of total glucan was detected $(p<0.10)$, while the lowest total glucan levels were observed in shiitake mushrooms roasted at $160{ }^{\circ} \mathrm{C}(34.84 \%)$. The levels of $\alpha$-glucan were generally lower than $\beta$-glucan, indicating that most of the glucan found in shiitake mushrooms is $\beta$-glucan, regardless of the roasting conditions. The highest content of $\beta$-glucan was shown at $120^{\circ} \mathrm{C}$, and the lowest at $160{ }^{\circ} \mathrm{C}(41.49 \%$ and $34.86 \%$, respectively; $p<0.10)$, which is a similar pattern to that seen in total glucan.

The $\beta$-glucan contents reported in this study were in agreement with the $\beta$-glucan contents reported in other studies: One study reported the different levels of $\beta$-glucan in the cap and stalk of shiitake mushrooms prepared at $60{ }^{\circ} \mathrm{C}$ for $16 \mathrm{~h}$ as $19.78 \%$ and $35.31 \%$, respectively [19]. Another study reported that the $\beta$-glucan content in shiitake mushrooms dried at $40{ }^{\circ} \mathrm{C}$ was $24.18 \%$ [20]. A $\beta$-glucan content of freeze-dried shiitake mushroom was reported around $28.3 \%$ of the total weight, which was similar to the quantity in heated shiitake mushrooms [21]. It is also worth noting that the total and $\beta$-glucan contents were proportional to the increase in temperature until $120^{\circ} \mathrm{C}$ in this study. A decreasing tendency was observed at temperatures above $120^{\circ} \mathrm{C}$. Similar patterns have previously been reported, in that the release of $\beta$-glucan from barley increased as the extraction temperature increased [22]. Another study also reported an increase in $\beta$-glucan in shiitake mushrooms with an increase in the drying temperature of the mushrooms [23].

Table 3. Total-, $\alpha$ - and $\beta$-glucan contents of shiitake mushroom roasted in different temperatures.

\begin{tabular}{cccc}
\hline & Total Glucan $(\% w / w)$ & $\alpha$-glucan $(\% w / w)$ & $\beta$-glucan (\% w/w) \\
\hline $80^{\circ} \mathrm{C}$ & $36.93^{\mathrm{a}, \mathrm{b}} \pm 2.89$ & $0.24^{\mathrm{a}} \pm 0.15$ & $36.69^{\mathrm{a}, \mathrm{b}} \pm 2.88$ \\
$100^{\circ} \mathrm{C}$ & $36.03^{\mathrm{a}, \mathrm{b}} \pm 4.20$ & $0.11^{\mathrm{a}} \pm 0.25$ & $35.92^{\mathrm{a}, \mathrm{b}} \pm 4.41$ \\
$120^{\circ} \mathrm{C}$ & $41.61^{\mathrm{a}} \pm 3.95$ & $0.12^{\mathrm{a}} \pm 0.09$ & $41.49^{\mathrm{a}} \pm 4.02$ \\
$140^{\circ} \mathrm{C}$ & $37.02^{\mathrm{a}, \mathrm{b}} \pm 3.82$ & $0.06^{\mathrm{a}} \pm 0.13$ & $36.96^{\mathrm{a}, \mathrm{b}} \pm 3.80$ \\
$160^{\circ} \mathrm{C}$ & $34.84^{\mathrm{b}} \pm 4.08$ & $0.02^{\mathrm{a}} \pm 0.21$ & $34.86^{\mathrm{b}} \pm 4.20$ \\
$180^{\circ} \mathrm{C}$ & $37.05^{\mathrm{a}, \mathrm{b}} \pm 3.94$ & $0.10^{\mathrm{a}} \pm 0.12$ & $36.96^{\mathrm{a}, \mathrm{b}} \pm 3.82$ \\
\hline
\end{tabular}

${ }^{a-c}$ Geometric means within a column with different letters are different $(p<0.10)$.

\subsection{Volatile Flavor Analysis Results}

Figure 1 shows the total peak area of shiitake mushrooms roasted at six different temperatures. The shiitake mushrooms roasted at $160^{\circ} \mathrm{C}$ had the highest total peak area with $2,242,208$, followed by $180{ }^{\circ} \mathrm{C}(1,783,266)$, and $140{ }^{\circ} \mathrm{C}(1,074,749)$, indicating that the mushroom samples roasted at $160{ }^{\circ} \mathrm{C}$ had the most diverse volatile flavor profiles. The increment of the total peak area according to the increase in roasting temperature has been reported in a previous study [24].

Twenty-six volatile aromatic compounds were identified in the shiitake samples roasted at different temperatures (Table 4 ). The 26 volatile compounds identified included the following: eight aldehydes, including isobutyraldehyde, 3-methyl butanal, 2-methyl butanal, 2-methyl-2-butenal, pentanal, 2-methyl pentanal, hexanal, and benzaldehyde; four sulfur-containing compounds, namely carbon disulfide, thiophene, dimethyl disulfide, and 2-methylthiophene; four alcohols, including 2-pentanol, 3-methyl 1-butanol, 2-methyl 1-butanol, and 1-pentanol; three pyrazines, 2-methyl pyrazine, 2,5-dimethyl pyrazine, and 2,3,5-trimethyl pyrazine, and seven other compounds. Four compounds, namely benzene, 3-methyl butanal, 2-methyl butanal, and 1,3,5,7-cyclooctatetraene, were detected in all the shiitake mushroom samples roasted at six different temperatures. 


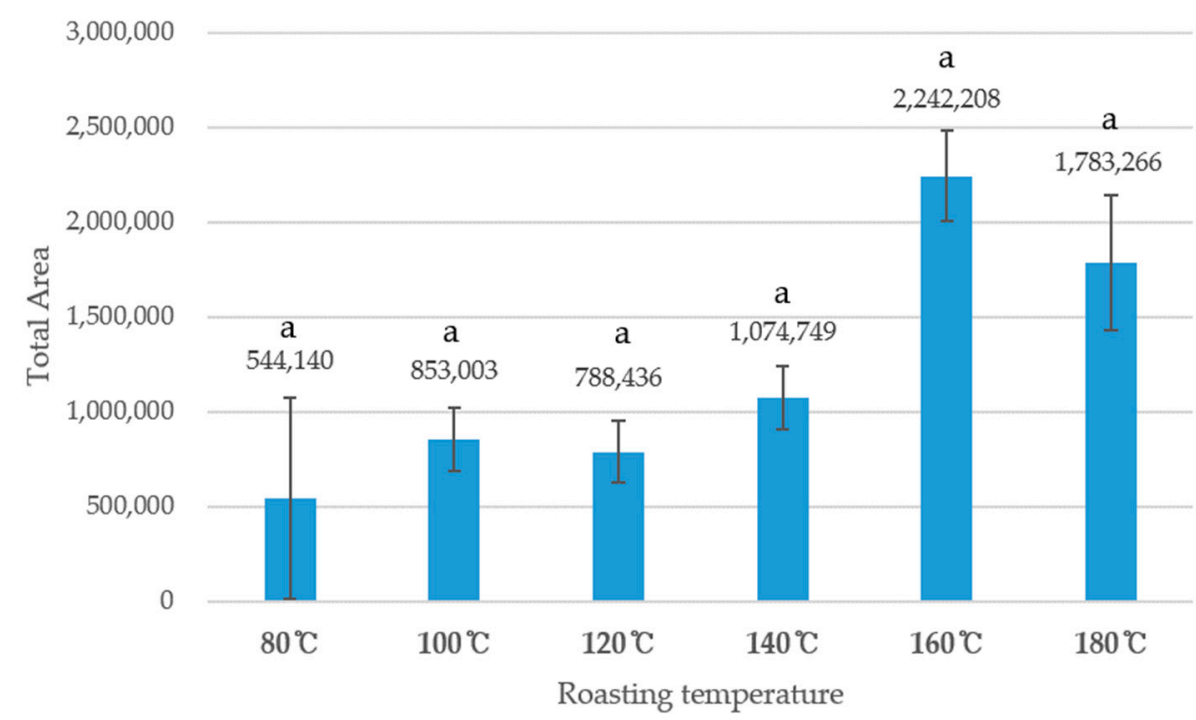

Figure 1. Total Peak Area of shiitake mushroom roasted in six different temperatures. $80^{\circ} \mathrm{C}$ represents shiitake mushroom roasted at $80^{\circ} \mathrm{C} ; 100{ }^{\circ} \mathrm{C}$ represents shiitake mushroom roasted at $100{ }^{\circ} \mathrm{C} ; 120^{\circ} \mathrm{C}$ represents shiitake mushroom roasted at $120^{\circ} \mathrm{C} ; 140^{\circ} \mathrm{C}$ represents shiitake mushroom roasted at $140{ }^{\circ} \mathrm{C} ; 160{ }^{\circ} \mathrm{C}$ represents shiitake mushroom roasted at $160{ }^{\circ} \mathrm{C}$. Alphabetical letter "a" followed by numbers represent no significant differences in peak area ration between shiitake mushroom samples roasted in different temperatures.

Table 4. Volatile flavor analysis results of shitake mushroom roasted in different temperatures.

\begin{tabular}{|c|c|c|c|c|c|c|c|c|c|c|}
\hline \multirow{2}{*}{ Peak \# } & \multirow{2}{*}{ R. Time } & \multirow[b]{2}{*}{ Compound Name } & \multirow[b]{2}{*}{ Aroma Description } & \multirow[b]{2}{*}{ Ref. } & \multicolumn{6}{|c|}{ Peak Area Ratio (\%) } \\
\hline & & & & & $80^{\circ} \mathrm{C}$ & $100^{\circ} \mathrm{C}$ & $120^{\circ} \mathrm{C}$ & $140^{\circ} \mathrm{C}$ & $160^{\circ} \mathrm{C}$ & $180^{\circ} \mathrm{C}$ \\
\hline 1 & 4.013 & Carbon disulfide & Solventy, sweet & [25] & 3.68 & 6.06 & 3.1 & & & 4.05 \\
\hline 2 & 4.927 & Isobutyraldehyde & $\begin{array}{l}\text { Malty, green, } \\
\text { pungent }\end{array}$ & [26] & 4.64 & 5.88 & 5.8 & 5.07 & 3.57 & \\
\hline 3 & 7.182 & Benzene & Sweet, solventy & [25] & 23.27 & 11.83 & 17.8 & 11.38 & 6.46 & 26.54 \\
\hline 4 & 7.359 & 3-methyl butanal & Nutty, malty & [11] & 23.97 & 33.41 & 37.1 & 23.81 & 5.15 & 17.81 \\
\hline 5 & 7.463 & Thiophene & Garlic & [25] & & & 30 & & 1.24 & \\
\hline 6 & 7.556 & 2-methyl butanal & Nutty, malty & [11] & 11.39 & 23.4 & 6.2 & 30.61 & 16.52 & 9.34 \\
\hline 7 & 7.659 & 2-methyl-2-butenal & Green, Fruit & [27] & & 2.75 & & & & \\
\hline 8 & 8.227 & 2-pentanol & Pungent & [28] & & & & 5.84 & 5.95 & \\
\hline 9 & 8.438 & Pentanal & Nutty, Malty & [29] & & & & & 2.29 & \\
\hline 10 & 9.484 & Dimethyl disulfide & Onion, Cabbage & {$[9,24]$} & & & & & 2.26 & \\
\hline 11 & 9.67 & 3-methyl 1-butanol & $\begin{array}{l}\text { Whiskey, malty, } \\
\text { burnt }\end{array}$ & [26] & 6.27 & 2.98 & & & & 7.01 \\
\hline 12 & 9.676 & 2-Methyl pentanal & - & & & & & 4.25 & 7.22 & \\
\hline 13 & 9.749 & 2-methyl 1-butanol & Malty, green, wine & [29] & 4.89 & 3.53 & & & & 6.01 \\
\hline 14 & 9.742 & Pyridine & - & & & & & & 6.21 & \\
\hline 15 & 9.857 & Methyl benzene & Paint & [30] & 4.58 & & & 2.83 & 4.51 & \\
\hline
\end{tabular}


Table 4. Cont.

\begin{tabular}{|c|c|c|c|c|c|c|c|c|c|c|}
\hline \multirow{2}{*}{ Peak \# } & \multirow{2}{*}{ R. Time } & \multirow[b]{2}{*}{ Compound Name } & \multirow[b]{2}{*}{ Aroma Description } & \multirow[b]{2}{*}{ Ref. } & \multicolumn{6}{|c|}{ Peak Area Ratio (\%) } \\
\hline & & & & & $80^{\circ} \mathrm{C}$ & $100^{\circ} \mathrm{C}$ & $120^{\circ} \mathrm{C}$ & $140^{\circ} \mathrm{C}$ & $160^{\circ} \mathrm{C}$ & $180^{\circ} \mathrm{C}$ \\
\hline 16 & 9.873 & Isoamyl phenyl acetate & - & & & & & & & 6.25 \\
\hline 17 & 10.036 & 2-Methylthiophene & Sulfur & {$[30]$} & & & & & 1.64 & \\
\hline 18 & 10.425 & 1-Pentanol & Pungent & & & & & & 2.17 & \\
\hline 19 & 10.941 & Hexanal & Grass, tallow, fat & [26] & & 2.2 & & 3.96 & 5.76 & 7.19 \\
\hline 20 & 11.495 & 2-methyl pyrazine & Popcorn & {$[30]$} & & & & & 1.44 & \\
\hline 21 & 12.9 & $\begin{array}{c}1,3,5,7- \\
\text { Cyclooctatetraene }\end{array}$ & - & & 11.51 & 7.97 & 3.73 & 12.26 & 6.86 & 15.79 \\
\hline 22 & 13.049 & 2-Heptanone & Soap & [26] & & & & & 1.13 & \\
\hline 23 & 13.366 & 2,5-dimethyl-Pyrazine & $\begin{array}{l}\text { Peanut butter, } \\
\text { solvent }\end{array}$ & [30] & & & & & 1.44 & \\
\hline 24 & 14.623 & 2-Pentyl furan & Beany & [29] & & & & & 7.58 & \\
\hline 25 & 14.987 & Benzaldehyde & $\begin{array}{l}\text { Almond, burnt } \\
\text { sugar }\end{array}$ & [27] & & & & & 2.43 & \\
\hline 26 & 15.18 & 2,3,5-trimethyl pyrazine & - & & & & & & 2.03 & \\
\hline
\end{tabular}

Peak area ratio (PAR) is the ratio of each peak area divided by total area.

As shown in Figure 1, the shiitake mushroom samples roasted at $160{ }^{\circ} \mathrm{C}$ had 21 different volatile compounds, while the other samples had between seven and 10 different volatile compounds. Previous studies have reported that alcohols are the major chemical family present in mature shiitake mushrooms, and the 1-octene-3-ol among alcohol group has been identified as the major volatile compound found in raw mature shiitake mushrooms [24,31]. In this study, 1-octene-3-ol was not found in the shiitake mushrooms, as all the samples were heated and dried. However, 2-methyl 1-butanol and 3-methyl-1butanol, which had whiskey, malty and burnt aromatics, were present in several shiitake mushroom samples (roasted at $80^{\circ} \mathrm{C}, 100^{\circ} \mathrm{C}$, and $180{ }^{\circ} \mathrm{C}$ ). In shiitake mushrooms roasted at $140{ }^{\circ} \mathrm{C}$ and $160^{\circ} \mathrm{C}$, 2-pentanol, which produces a balsamic aromatic was found, and 1-pentanol, which has a pungent aromatic, was found in mushrooms roasted at $160{ }^{\circ} \mathrm{C}$. Regarding sulfur-containing compounds, carbon disulfide, thiophene, dimethyl disulfide, and 2methylthiophene were identified in the shiitake mushroom samples. Straight-chain sulfur compounds, including dimethyl disulfide in this study, can provide onion and cabbage aromatics in general, which can produce the typical aromatics of fresh shiitake mushrooms and savory and meaty aromatics in dried mushrooms [10,24]. In this study, dimethyl disulfide was exclusively found in shiitake mushroom roasted in $160^{\circ} \mathrm{C}$ with $2.26 \%$ PAR. It has been reported that the low boiling point of straight-chain sulfur-containing compounds can impact the decrease of concentration during the drying process [32]. Therefore, the absence of dimethyl disulfide and other straight-chain sulfur-containing compounds in shiitake mushroom samples may be attributed to the volatility of these compounds. Nutty and malty aromatic characteristics have previously been noted with 2-methyl butanal and 3-methyl butanel [11]. These two compounds were present in all the roasted shiitake mushroom samples in this study, ranging between $5.15 \%$ and $37.1 \%$ for 3-methyl butanal and $2 \%$ and $30.61 \%$ for 2 -methyl butanal. These two compounds are Strecker aldehydes, formed by the Streker degradation process in various foods [11]. The presence of these two Strecker aldehydes may be attributed to the Strecker degradation process during the heated drying process in shiitake mushrooms.

\subsection{Correlation of the Antioxidant Properties, Glucan Content, and Volatile Flavor Analysis Results}

Figure 2 shows a PCA biplot on the antioxidant, $\beta$-glucan, and volatile flavor profiles of shiitake mushrooms roasted at six different temperatures. This biplot demonstrates how 
each shiitake mushroom sample is located in the antioxidant, glucan contents $(\alpha-, \beta$, and total) and volatile flavor profile map. The shiitake mushroom samples were differentiated by their volatile flavor profiles, in that the more abundant flavor compounds were present with an increase in roasting temperature. It is worth noting that the shiitake mushroom sample roasted at $180^{\circ} \mathrm{C}$ shares similar volatile flavor profiles with mushrooms roasted at $80^{\circ} \mathrm{C}$, indicating a loss of volatile flavor compounds when roasting at too high a temperature. As for antioxidant properties, a high correlation between the total phenol (free), polyphenol contents, TEAC (free) and DPPH (\%) were observed, and antioxidant properties were characteristic of shiitake mushrooms roasted at 140 . The shiitake mushroom samples roasted at $100{ }^{\circ} \mathrm{C}$ and $120^{\circ} \mathrm{C}$ had a high correlation to the total and $\beta$-glucan contents. These samples, high in glucan (total and $\beta$-), tended to have 2-methyl 2- butenal, 3-methyl butanal, and thiophene. The shiitake mushrooms roasted at $80^{\circ} \mathrm{C}$ had a high correlation to $\alpha$-glucan content and carbon disulfide. The correlation matrix of antioxidant activities, glucan contents, and instrumental flavor analysis results of shiitake mushrooms dried in 6 different degrees is illustrated in Table S1.

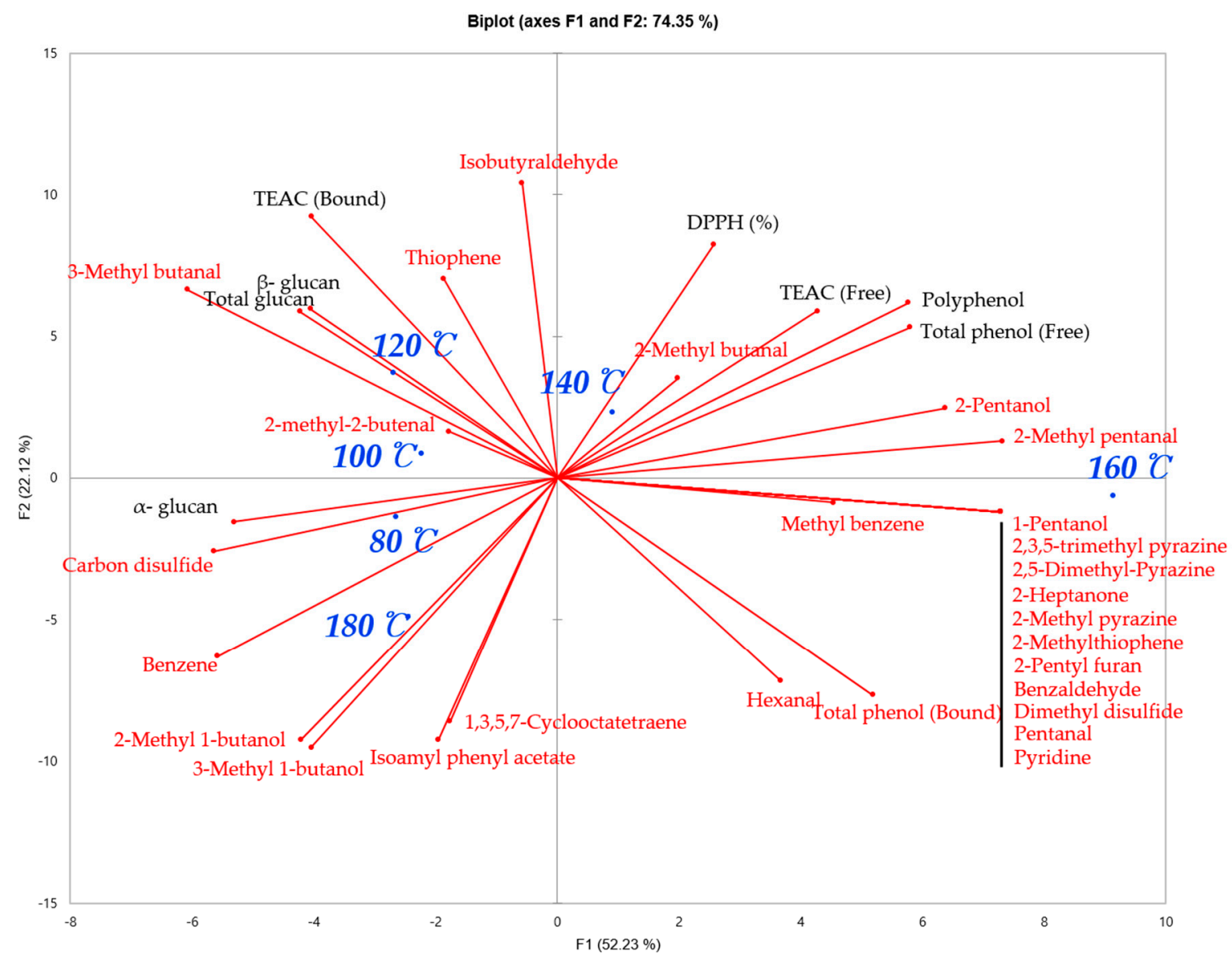

Figure 2. Principal Component Analysis Biplot on antioxidant, $\beta$-glucan and volatile flavor profiles of shiitake mushroom roasted in six different temperatures. $80{ }^{\circ} \mathrm{C}$ represents shiitake mushroom roasted at $80{ }^{\circ} \mathrm{C} ; 100{ }^{\circ} \mathrm{C}$ represents shiitake mushroom roasted at $100{ }^{\circ} \mathrm{C} ; 120^{\circ} \mathrm{C}$ represents shiitake mushroom roasted at $120^{\circ} \mathrm{C} ; 140{ }^{\circ} \mathrm{C}$ represents shiitake mushroom roasted at $140{ }^{\circ} \mathrm{C} ; 160^{\circ} \mathrm{C}$ represents shiitake mushroom roasted at $160{ }^{\circ} \mathrm{C}$.

\section{Conclusions}

This study investigated the influence of roasting conditions on the volatile flavor profiles and functional properties of shiitake mushrooms. The results show that shiitake mushrooms roasted at $140^{\circ} \mathrm{C}$ have high antioxidant activity. Shiitake mushrooms roasted at $160^{\circ} \mathrm{C}$ have the most abundant flavor profiles. An increase in roasting tempera- 
ture increases the overall flavor abundance up to $160{ }^{\circ} \mathrm{C}$, while roasting at temperatures higher than $160{ }^{\circ} \mathrm{C}$ can decrease the overall flavor abundance of shiitake mushrooms. The finding from this study suggests the cooking direction of shiitake mushroom, in that roasting shiitake mushroom at $100-120^{\circ} \mathrm{C}$ is recommended for functional benefits while roasting mushroom at higher temperature $\left(160^{\circ} \mathrm{C}\right)$ can maximize the authentic flavor of shiitake mushrooms.

Supplementary Materials: The following are available online at https:/ / www.mdpi.com/2304-8 158/10/1/54/s1, Table S1: Correlation matrix among instrumental flavor analysis, antioxidant activities, and functional activity (glucan contents) results.

Author Contributions: Data analysis and writing volatile flavor analysis section, I.-S.H.; Data analysis in antioxidant properties and shiitake mushroom characteristics, S.-Y.C.; Writing introduction and funding, W.-S.B.; Overall conceptualization, writing review and editing, supervision, M.K.K. All authors have read and agreed to the published version of the manuscript.

Funding: This research was funded by the 2019 (219A380179) Yeungnam University Research Grant and Basic Science Research Program through the National Research Foundation of Korea (NRF) funded by the Ministry of Science, ICT \& Future Planning (Grant number: NRF-2020R1C1C1011279). And The APC was funded by Yeungnam University Research Grant and National Research Foundation of Korea (NRF).

Institutional Review Board Statement: Not applicable.

Informed Consent Statement: Not applicable.

Data Availability Statement: Data is contained within the article .

Acknowledgments: This research was supported by the 2019 (219A380179) Yeungnam University Research Grant and Basic Science Research Program through the National Research Foundation of Korea (NRF) funded by the Ministry of Science, ICT \& Future Planning (Grant number: NRF2020R1C1C1011279). Further, part of this research was funded by Korea National Food Cluster R\&D Support program. Additionally, authors thank Yun-Jo Chung for volatile flavor analysis, at the Center for University Research Facility (CURF) in Jeonbuk National University.

Conflicts of Interest: Authors declare no conflict of interests

\section{References}

1. Her, J.-Y.; Kim, M.S.; Kim, M.K.; Lee, K.-G. Development of a spray freeze-drying method for preparation of volatile shiitake mushroom (Lentinus edodes) powder. Int. J. Food Sci. Technol. 2015, 50, 2222-2228. [CrossRef]

2. Jiang, T.; Luo, Z.; Ying, T. Fumigation with essential oils improves sensory quality and enhanced antioxidant ability of shiitake mushroom (Lentinus edodes). Food Chem. 2015, 172, 692-698. [CrossRef] [PubMed]

3. KOSTAT. Results of the Agriculture, Forestry and Fishery Survey in 2017. Available online: http://kostat.go.kr/portal/eng/ pressReleases / 2/4/index.board (accessed on 11 November 2020).

4. Chan, G.C.F.; Chan, W.K.; Sze, D.M.-Y. The effects of $\beta$-glucan on human immune and cancer cells. J. Hematol. Oncol. 2009, 2, 1-11. [CrossRef] [PubMed]

5. Dabal, A.; Ezeronye, O. Anti-cancer effect of polysaccharides isolated from higher basidiomycetes mushrooms. Afr. J. Biotechnol. 2003, 2, 672-678. [CrossRef]

6. Bae, I.Y.; Kim, H.W.; Yoo, H.J.; Kim, E.S.; Lee, S.; Park, D.Y.; Lee, H.G. Correlation of branching structure of mushroom $\beta$-glucan with its physiological activities. Food Res. Int. 2013, 51, 195-200. [CrossRef]

7. Cho, J.-H.; Lee, J.-Y.; Lee, M.-J.; Oh, H.-N.; Kang, D.-H.; Jhune, C.-S. Comparative analysis of useful $\beta$-glucan and polyphenol in the fruiting bodies of Ganoderma spp. J. Mushroom 2013, 11, 164-170. [CrossRef]

8. Fu, H.-Y.; Shieh, D.-E.; Ho, C.-T. Antioxidant and free radical scavenging activities of edible mushrooms. J. Food Lipids 2002, 9, 35-43. [CrossRef]

9. De Pinho, P.G.; Ribeiro, B.; Gonçalves, R.F.; Baptista, P.; Valentão, P.; Seabra, R.M.; Andrade, P. Correlation between the pattern volatiles and the overall aroma of wild edible mushrooms. J. Agric. Food Chem. 2008, 56, 1704-1712. [CrossRef]

10. Dermiki, M.; Phanphensophon, N.; Mottram, D.S.; Methven, L. Contributions of non-volatile and volatile compounds to the umami taste and overall flavour of shiitake mushroom extracts and their application as flavour enhancers in cooked minced meat. Food Chem. 2013, 141, 77-83. [CrossRef]

11. Kim, M.; Drake, S.; Drake, M. Evaluation of key flavor compounds in reduced- and full-fat cheddar cheeses using sensory studies on model systems. J. Sens. Stud. 2011, 26, 278-290. [CrossRef] 
12. Wang, H.-C.; Zhang, M.; Adhikari, B. Drying of shiitake mushroom by combining freeze-drying and mid-infrared radiation. Food Bioprod. Process. 2015, 94, 507-517. [CrossRef]

13. Krygier, K.; Sosulski, F.; Hogge, L. Free, esterified, and insoluble-bound phenolic acids. 1. Extraction and purification procedure. J. Agric. Food Chem. 1982, 30, 330-334. [CrossRef]

14. Cheung, L.M.; Cheung, P.C.K.; Ooi, V.E.C. Antioxidant activity and total phenolics of edible mushroom extracts. Food Chem. 2003, 81, 249-255. [CrossRef]

15. Choi, Y.; Lee, S.M.; Chun, J.; Lee, H.; Lee, J. Influence of heat treatment on the antioxidant activities and polyphenolic compounds of Shiitake (Lentinus edodes) mushroom. Food Chem. 2006, 99, 381-387. [CrossRef]

16. Dewanto, V.; Wu, X.; Liu, R.H. Processed sweet corn has higher antioxidant activity. J. Agric. Food Chem. 2002, 50, 4959-4964. [CrossRef]

17. Jeong, S.-M.; Kim, S.-Y.; Kim, D.-R.; Jo, S.-C.; Nam, K.C.; Ahn, A.D.U.; Lee, S.-C. Effect of heat treatment on the antioxidant activity of extracts from citrus peels. J. Agric. Food Chem. 2004, 52, 3389-3393. [CrossRef]

18. Gahler, S.; Otto, K.; Böhm, V. Alterations of Vitamin C, Total Phenolics, and antioxidant capacity as affected by processing tomatoes to different products. J. Agric. Food Chem. 2003, 51, 7962-7968. [CrossRef]

19. Sari, M.; Prange, A.; Lelley, J.I.; Hambitzer, R. Screening of beta-glucan contents in commercially cultivated and wild growing mushrooms. Food Chem. 2017, 216, 45-51. [CrossRef]

20. Jamil, N.A.M.; Rahmad, N.; Rashid, N.M.N.; Yusoff, N.; Yuswan, M.H.; Shaharuddin, S.; Saleh, N.M. LCMS-QTOF Determination of Lentinan-like $\beta$-D-glucan content isolated by hot water and alkaline solution from tiger's milk mushroom, termite mushroom, and selected local market mushrooms. J. Mycol. 2013, 2013, 1-8. [CrossRef]

21. Chanput, W.; Reitsma, M.; Kleinjans, L.; Mes, J.J.; Savelkoul, H.F.J.; Wichers, H.J. $\beta$-Glucans are involved in immune-modulation of THP-1 macrophages. Mol. Nutr. Food Res. 2012, 56, 822-833. [CrossRef]

22. Kanauchi, M.; Bamforth, C. Release of $\beta$-glucan from cell walls of starchy endosperm of Barley. Cereal Chem. J. 2001, 78, 121-124. [CrossRef]

23. Je, H.-J.; Kim, H.Y.; Ha, G.-J.; Ha, I.; Cho, S.R. Quality characteristics of Pleurotus eryngii, Lentinus edodes GNA01 and Grifola frondosa as affected by different drying methods. J. Korean Soc. Food Preserv. 2018, 25, 181-188. [CrossRef]

24. Tian, Y.; Zhao, Y.; Huang, J.; Zeng, H.; Zheng, B. Effects of different drying methods on the product quality and volatile compounds of whole shiitake mushrooms. Food Chem. 2016, 197, 714-722. [CrossRef] [PubMed]

25. Ruth, J.H. Odor thresholds and irritation levels of several chemical substances: A review. Am. Ind. Hyg. Assoc. J. 1986, 47, A-142-A-151. [CrossRef] [PubMed]

26. Santos, A.B.; Fernandes, A.S.; Wagner, R.; Jacob-Lopes, E.; Zepka, L.Q. Biogeneration of volatile organic compounds produced by Phormidium autumnale in heterotrophic bioreactor. J. Appl. Phycol. 2016, 28, 1561-1570. [CrossRef]

27. Wang, L.-B.; Bai, J.; Yu, Z.-F. Difference in volatile profile between pericarp tissue and locular gel in tomato fruit. J. Integr. Agric. 2016, 15, 2911-2920. [CrossRef]

28. Sabatini, N.; Mucciarella, M.R.; Marsilio, V. Volatile compounds in uninoculated and inoculated table olives with Lactobacillus plantarum (Olea europaea L., cv. Moresca and Kalamata). LWT_Food Sci. Technol. 2008, 41, 2017-2022. [CrossRef]

29. Griglione, A.; Liberto, E.; Cordero, C.; Bressanello, D.; Cagliero, C.; Rubiolo, P.; Bicchi, C.; Sgorbini, B. High-quality Italian rice cultivars: Chemical indices of ageing and aroma quality. Food Chem. 2015, 172, 305-313. [CrossRef]

30. Comuzzo, P.; Tat, L.; Tonizzo, A.; Battistutta, F. Yeast derivatives (extracts and autolysates) in winemaking: Release of volatile compounds and effects on wine aroma volatility. Food Chem. 2006, 99, 217-230. [CrossRef]

31. Cho, D.-B.; Seo, H.-Y.; Kim, K.-S. Analysis of the volatile flavor compounds produced during the growth stages of the shiitake mushrooms (Lentinus edodes). Prev. Nutr. Food Sci. 2003, 8, 306-314. [CrossRef]

32. Hiraide, M.; Miyazaki, Y.; Shibata, Y. The smell and odorous components of dried shiitake mushroom, Lentinula edodes I: Relationship between sensory evaluations and amounts of odorous components. J. Wood Sci. 2004, 50, 358-364. [CrossRef] 